\title{
Towards increased innovativeness and sustainability through organizational culture: A case study of a Finnish construction business
}

Ville Matinaro and Yang Liu

The self-archived postprint version of this journal article is available at Linköping University Institutional Repository (DiVA):

http://urn.kb.se/resolve?urn=urn:nbn:se:liu:diva-133158

N.B.: When citing this work, cite the original publication.

Matinaro, V., Liu, Y., (2017), Towards increased innovativeness and sustainability through organizational culture: A case study of a Finnish construction business, Journal of Cleaner Production, 142, 3184-3193. https://doi.org/10.1016/j.jclepro.2016.10.151

Original publication available at:

https://doi.org/10.1016/j.jclepro.2016.10.151

Copyright: Elsevier

http://www.elsevier.com/

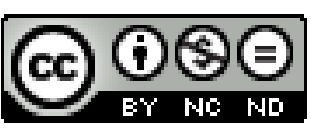




\section{Accepted Manuscript}

Towards increased innovativeness and sustainability through organizational culture: A case study of a Finnish construction business

Ville Matinaro, Yang Liu

PII: S0959-6526(16)31782-6

DOI: $\quad$ 10.1016/j.jclepro.2016.10.151

Reference: JCLP 8342

To appear in: Journal of Cleaner Production

Received Date: 12 July 2016

Revised Date: 24 September 2016

Accepted Date: 26 October 2016

Please cite this article as: Matinaro V, Liu Y, Towards increased innovativeness and sustainability through organizational culture: A case study of a Finnish construction business, Journal of Cleaner Production (2016), doi: 10.1016/j.jclepro.2016.10.151.

This is a PDF file of an unedited manuscript that has been accepted for publication. As a service to our customers we are providing this early version of the manuscript. The manuscript will undergo copyediting, typesetting, and review of the resulting proof before it is published in its final form. Please note that during the production process errors may be discovered which could affect the content, and all legal disclaimers that apply to the journal pertain. 
Towards increased innovativeness and sustainability through organizational culture: A case study of a Finnish construction business

\author{
Ville Matinaro ${ }^{a}$, Yang Liu ${ }^{b, a *}$ \\ ${ }^{a}$ Department of Production, University of Vaasa, PL 700, 65101 Vaasa, Finland \\ ${ }^{\mathrm{b}}$ Department of Management and Engineering, Linköping University, SE-581 83 Linköping, Sweden \\ E-mail: matinaro@gmail.com (V. Matinaro) \\ *Corresponding author: yang.liu@liu.se, yang.liu@uva.fi (Y. Liu)
}

\begin{abstract}
:
In the Finnish construction business, innovation management is considered to be difficult. However, cultural transition towards more innovative and creative thinking in construction industry can have vital impact on sustainability nationally and globally. There is an urgent need to examine at a more detailed level innovativeness in the construction companies and especially the manager's abilities to manage innovative organizational culture. It appears that lacks in managing culture and people with difficulties to understand key elements of innovativeness in organizational context seems to be a barrier towards increased innovativeness. The main finding is that the managers in construction industry cannot manage or create culture towards innovativeness. Therefore, there is major sector level lacks in innovativeness that have negative impact on societal change towards sustainability. This paper focus on managing organizational culture to reveal innovativeness in the case company that is vital for sustainability.
\end{abstract}

Keywords: construction, organizational culture, innovation, sustainability, transition

\title{
1 Introduction
}

In research, innovation is considered to be a very complex and multidimensional process in organization or social system connected to organizational culture. According to Nonaka \& Teece (2001) innovation management is a complex process of managing knowledge and information in organizations highlighting the inter-organizational collaboration between internal and external organizations. Schøtt \& Jensen (2016) states that networking benefits both process and product innovation. Kotter has studied that only through leadership it is possible to develop and care for culture that is adaptive to change (Kotter 1998:166). Sarros et al. (2008) states that there are two differing schools of thought about leaders and culture.

The functionalist school argues that leaders are the true architects of culture change through substantive or visible actions they make or through the symbolic roles they play (Meindl et al. 1985, Schein 2004, Sarros et al. 2008). The anthropological view questions about the veracity of leaders' being able to create new culture because organization leaders are part of exiting organizational culture and not apart from it (Smircich 1983, Meek 1988). It seems that in research the functionalist perspective is in favour arguing that leaders are in a rather crucial position to shape the organization's culture by shaping the organizational environment (Denison \& Mishra 1995, Schneider et al. 1995). Therefore, organizational culture is crucial factor when increasing innovativeness in organizations.

If the social system is something like construction industry with a very diverse and a multileveled nature, it seems to be that there is no single way to explain how innovations will occur or how culture can be managed. Nevertheless, Ogbonna \& Harris (2000:780) have found a link connecting participative leadership and innovative organizational culture as a forecaster of organizational performance. Geert Hofstede (2010:24) states that organizations are culture bound and therefore act in a certain way. To be successful, organizations must constantly create new ideas on how to improve their operations towards innovativeness to maintain competitiveness (Porter, 1985; Damanpour, 1991; Kessler \& Chakarbati 1996; Tidd, 2001; Liu 2013; Nagano et al. 2014; Arundel et.al 2015; Liu \& Liang 2015). Organization must create diversity and use practices such as open innovation by themselves to be innovative in their own organizational context. This is highly important industries like construction industry in transitions towards more sustainable approaches. 
As Schumpeter has stated, innovativeness in organization is something like carrying out new combinations (Schumpeter, 1934:65). Therefore, creating diversity in organization most likely increases innovativeness. According to research, it is common that companies do not have sufficient innovation and leadership culture in their organization. Nevertheless, Damanpour \& Schneider (2006:220) argues that managers influence organizational outcomes by establishing organizational culture influencing organizational climate and building the capacity for change and innovation. According to them climate for innovation is a direct result of top managers personal and positional characteristics. Tabassi et al. (2016) argues that that leadership competencies, transformational leadership and intellectual competence of project managers plays the most significant role in sustainable construction. It appears that managers' ability to create innovative culture is bound to their characteristics and are crucial for construction and use of sustainable solutions in the industry.

The relevance of innovations and innovative organizational culture in the companies can be described well with Chesbourgh's thoughts. He states that most of the innovations will fail, but companies that do not innovate will die (Chesbrough, 2003:17). According to Cho et al. (2016), firm and manager characteristics explain a large portion of the variation in a firm's innovation productivity. This paper argues that the origin of innovativeness lies in the organizational culture characteristics and managers abilities to manage culture and people. Therefore, the most essential matter towards innovativeness in Finnish construction industry is to create an innovative organizational culture that will lead to increased innovativeness and sustainability over time. Kotler et al. (1990) states that behind every successful and innovative corporation there is a mutual organizational culture that fits to overall strategy.

In related literature, producing innovations in construction industry is generally considered far more difficult than in other industries due to its characteristics (Barret, 2007; Widén \& Hansson, 2007; Bygballe \& Ingnemasson 2014; Eriksson 2014; Matinaro \& Liu, 2015). Still the organization's ability to innovate is generally accepted as one of the most important factors of organization's overall success (Chapman et al. 2004). According to Winch (1998), the rate of innovations is rather low in construction industry compared to other industries. This can be identified from the following senior project manager statement of the case company:

“There should be much, much more innovativeness in construction (n10)”.

Construction projects consist of a variety of interaction with different stakeholders in many levels in the organization that is considered to be a needed aspect of increased innovation performance. Bygballe \& Ingnemasson (2014) have studied that these specific multilevel and inter-organizational characteristics can be of an important role of construction industries' innovativeness. It is highly paradoxical that an industry, which works by its nature in a collaborative way within societies and which effects to economies are enormous cannot be innovative enough. This refers to lacks of creating the innovative culture and moreover to overall difficulties to lead innovativeness.

It seems that the persistent problem in construction industries overall innovativeness is not in the actual operating models or methods including operative functions. Instead, there are indications that the lack of managers abilities to manage culture and people appears to be behind many well-known difficulties concerning to innovativeness and sustainable approaches in construction. According to Alwan et al. (2016), there are variety of causes found in literature that are against strategic sustainable development in construction. These causes include ineffective leadership, ingrained cultures, outdated technologies, poor logistics and lack of using solutions such as BIM (Building Information Modeling). Hogan \& Coote (2014) states that layers of organizational culture, like innovative behaviours, support innovation and firm performance.

Vesa (2014) has stated in his research that managers can significantly slow down innovativeness if they cannot facilitate it (Table 1). He continues that innovation management cannot be separated from daily 
management practices and is something that cannot be externalize. He argues that especially organizations in construction industry must carefully consider this when new managers are hired in organizations. He summarizes that it is important that acting management be not out of comfort zone when leading or facilitating innovativeness in organizations (Vesa 2014). According to Tushman \& O'Reilly (1997), organization culture is key element of the organization innovativeness. They continue that successful organizations have the abilities to adapt innovation into the organizational culture and management processes.

Martins \& Terblanche (2003: 67-68) have studied that the degree of support and encouragement in an organization provides its employees to take initiative and explore innovative approaches is predicted to influence the degree of actual innovation in that organization. This is exactly what managers should be done in adopting sustainable approaches and use of rather new clean-tech solutions or new sustainable business models. Nevertheless, managers are usually not good at managing the culture (Tushman \& Andersson 1997:200). Therefore, organizational culture can significantly increase organizations innovativeness or decrease it.

Schein (2004:407) emphasizes that especially in times of cultural change leaders or managers have a fundamental role. He argues that leaders must be "learning leaders", because during a change in culture leaders need persistence and patience, but also flexibility and readiness to change. According to Lee et al. (2008), there are seen connections between organizational culture, organizational learning and innovation performance. Damanpour (1991) have found out in his meta-analysis that there are ten significant organizational elements of innovation and culture is one of them. These elements are fundamental ones when increasing innovativeness in organizations and key practices of innovation management.

It may be that the culture in a construction industry companies are not well managed. Managers are unable to renew organizational culture towards innovativeness that affect significantly sustainability. Construction industry is often labelled to be a traditional one with its approaches. Therefore, researching organizational culture and its connections to innovativeness in construction industry is highly important. It appears that in related literature there are rather few studies trying to connect innovativeness in culture of organizations (McLean, 2005:241; Valencia et al. 2010).

Table 1: Factors in the case company's organizational culture that is decreasing innovativeness.

\begin{tabular}{|c|c|c|}
\hline Observed dificulties & Solutions & Changed organizational culture \\
\hline $\begin{array}{l}\text { The anthrop } \\
\text { perspect }\end{array}$ & The functionalist perspective & The functionalist perspective \\
\hline $\begin{array}{l}\text { Leaders' can't create new } \\
\text { culture or change existing one }\end{array}$ & $\begin{array}{l}\text { Leaders must take responsibility of } \\
\text { culture change }\end{array}$ & $\begin{array}{l}\text { Leaders and managers thrives } \\
\text { for change }\end{array}$ \\
\hline No learning leaders & $\begin{array}{l}\text { Ability to act as learning leaders, } \\
\text { open minded approaches, ability to } \\
\text { renew }\end{array}$ & $\begin{array}{l}\text { Transformational leadership, } \\
\text { innovative approaches }\end{array}$ \\
\hline $\begin{array}{l}\text { Difficulties to lead culture and } \\
\text { people }\end{array}$ & $\begin{array}{l}\text { Increasing understanding of soft } \\
\text { management methods and leading the } \\
\text { people, culture and innovations }\end{array}$ & $\begin{array}{c}\text { Increased employee satisfaction } \\
\text { and organizational } \\
\text { innovativeness }\end{array}$ \\
\hline $\begin{array}{l}\text { Lack of diversity in } \\
\text { organizations }\end{array}$ & Increasing diversity in organizations & $\begin{array}{c}\text { New thoughts to organization, } \\
\text { new combinations, new } \\
\text { innovations, new know-how, } \\
\text { change }\end{array}$ \\
\hline $\begin{array}{l}\text { Scattered organizational } \\
\text { structure }\end{array}$ & $\begin{array}{l}\text { Increasing inter-organizational } \\
\text { cooperation, avoid traditional } \\
\text { structures }\end{array}$ & $\begin{array}{l}\text { Organizational culture is more } \\
\text { easy to communicate and lead }\end{array}$ \\
\hline
\end{tabular}




\begin{tabular}{|c|c|c|}
\hline Strong sub-cultures & $\begin{array}{l}\text { Detecting sub-cultures and possible } \\
\text { unwanted behavior, detecting vicious } \\
\text { learning cycles, networking and }\end{array}$ & $\begin{array}{l}\text { Open-minded and coherent } \\
\text { organizational culture }\end{array}$ \\
\hline $\begin{array}{l}\text { Traditional human resource } \\
\text { practises }\end{array}$ & $\begin{array}{c}\text { communication } \\
\text { Finding out non-traditional } \\
\text { characteristics of managers and } \\
\text { employees, preventing homogeneous } \\
\text { organizations, effective work } \\
\text { circulation, facilitation methods }\end{array}$ & $\begin{array}{l}\text { Creating diversity in } \\
\text { organizations, key element of } \\
\text { change in construction }\end{array}$ \\
\hline Unwillingness to change & $\begin{array}{l}\text { Open-minded approaches, willingness } \\
\text { to change }\end{array}$ & $\begin{array}{l}\text { Better cooperation and } \\
\text { innovativeness throughout the } \\
\text { organization }\end{array}$ \\
\hline Non-innovative organization & Innovative organization & $\begin{array}{l}\text { Increased innovativeness } \\
\text { through cultural change }\end{array}$ \\
\hline
\end{tabular}

According to Rosca et al. (2016), sustainable innovations are inventions providing an essential progress concerning social, economic and ecological concerns. This fit well in context of construction industry with high societal status in economies, but very energy intensive way of operating. Several researchers have argued that there is an urgent need to educate managers towards more innovative approaches in general (Gosling \& Mintzberg 2004; Pesonen 2006; Muff 2010; Kane 2011). According to Apilo \& Taskinen (2006:8) innovation process and innovation strategy in organizations is supported by innovation structure and innovation culture.

The core innovation process in companies is highly relevant, but without an organizational innovation culture, structure and strategy, organizations cannot be as innovative as they could. Therefore, this paper claims that innovation culture is one of the weaknesses in construction industry companies that are keener towards hard management and operational results than leadership kind of leading, soft values, managing people and sustainability. According to Schein (2004:407), when changing organizational culture there are lots of anxiety involved in organizations and its groups when they are trying to learn away from old habits of doing things. Here, "learning leaders" with good leadership abilities are needed to support their organizations or groups in the organization (Schein, 2004:407). He continues that one of the key elements in cultural change is leader's abilities to say no even to his/her own organization (Schein, 2004:415-416). It appears that Finnish construction industry has failed to build up a supporting innovation culture to its organizations which is not ideal for innovations or use of more sustainable solutions.

The structure of this paper is as follows: Section 1 introduces the main subject areas of this study and recent research related to the topic. Section 2 introduces the aspects of innovation management and sustainability in construction industry. Section 3 introduces the methodology and analysis used. Section 4 deals with main results and key elements of managing innovative culture toward sustainability in construction. Section 5 is for discussion and future research and section 6 concludes this paper.

\section{Innovation management and sustainability in Finnish construction industry}

Innovation management in construction industry has been a very interesting topic for several researchers in recent years. Despites different definitions of an innovation, Balyse \& Manley (2004) paraphrase Slaughter (1998) that in construction industry academics and researcher have agreed that Slaughters (1998) definition of innovation,

\footnotetext{
"innovation is the actual use of a nontrivial change and improvement in a process, product, or system that is novel to the institution developing the change"
}

is one of the most suitable one for describing innovations in this industry. Because of the share size of construction industry, it is considered to be a backbone of modern economies and for these reasons 
innovative construction has high societal relevance (Erikson 2013). Because of this social status, lacks in capabilities to be innovative in construction sector may prevent social transitions towards sustainability, which can have huge society affects globally.

Difficulties behind the non-innovative organizations in construction are well described by Kiuru (2015) with statement that in construction industry stakeholder cooperation aims only for an operative business results and therefore operative goals are always dominating. He argues that it is obvious that in this kind of highly effective environment, innovations do not occur (Kiuru 2015). Although Tan et al. (2015) have found connections between sustainability performance and business competitiveness arguing that international contractors with higher sustainability performance will have higher revenues on the market they are operating. Therefore, sustainable development must be seen as an opportunity for construction industry, not as a cost. It seems that managing innovation and innovative culture is true weakness of construction industry. Trott (2008:581) argues that innovation process in organization is most of all human process. Therefore, humans must be lead through this process by managers. As anthropological view of managing culture states about culture and leaders it appears that in construction industry managers are not able to renew organizational culture because among them leadership kind of leading style and actual understanding of organizational culture may not be rather general.

Successful innovations in construction need effective cooperation, coordination and relationships between different stakeholders in actual projects (Ling 2003). Tatum (1987) states that leadership; supportive organizational structure, collaboration and customer orientation are the main enablers of innovation. All of these aspects are closely related to manager abilities to lead and create a supportive innovative culture in organization. According to Kiuru (2015) in construction projects there should be innovation processes to use for and much more unoccupied time to be innovative with stakeholders. Barret et al. (2007) have studied that innovations in construction industry are co-developed in project context and may be hidden from the company level. There are also indications that construction companies have problems in learning from projects to projects as Gann (2001) has stated, although organizational learning is a crucial factor for success, cultural change and innovativeness.

These research findings are highlighted in the construction industry sustainable studies. Ruparathna \& Hewage (2015) have found that there is a clear gap of knowledge of sustainability and sustainable initiatives have rarely been used in the construction industry, especially in procurement. They observed significant deficiency in bid evaluation regarding sustainability in practice while a majority of construction industry companies agreed that sustainability is necessity in the future. According to Bartsch (2013) learning across projects and inter-organizational boundaries are essential to extinguishing organizational learning barriers which project based industry has. Organizations in construction industry need to move over the boundaries of single organization and engage in collaborative networks. In these networks, multiple, diverse stakeholders are working together to co-create innovative value (Reypens et al. 2016). These aspects mentioned are closely linked to innovative organizational culture with highly cooperative approaches.

Powell (1997) states that especially project based learning and sharing information of best practices between projects are essential and often the best time to develop mutual practices. In construction companies project managers are in an essential role in these kinds of activities and forming the culture towards innovativeness. Project managers' abilities to spread and share information between sites could be one crucial factor in organizational innovativeness, but it appears that there no culture of doing that. According to Gann \& Salter (2000) project-based firms need to manage innovations and uncertainty across organizational boundaries, within networks of suppliers, customers and regulatory bodies. They continue that there is a need for a better conceptual understanding and new management practices to link project and business processes. Matja et al. (2016) have researched that corporate efficiency in sustainability practices and innovativeness will gain performance benefits for organizations. 
In a complex systems industry companies need to rely on other firms, contractors and subcontractors with rather less understanding of each other's working habits where culture of collaborate is essential. According to Balyse \& Manley (2004), producing innovations in this kind of environment can only be achieved by the collaboration between those concerned with the development of products, processes and designs. Kiuru (2015) states that it crucial for innovations to cooperate with stakeholders outside the actual operative projects and set the targets together in sector level context. He suggests that there should be common understanding and agreed practices on how to increase innovativeness in construction industry. If organizations have difficulties in managing an open and collaborative organizational culture cooperation mentioned above could be difficult.

There are elements in the Finnish construction industry that are not supportive for innovativeness or sustainability. In traditional, pragmatic and homogeneous environments approaches managing something like culture, can be difficult and even unthinkable. Next statements of the senior manager in the case company indicates this well:

"Our organization culture is very pragmatic. This is a major problem in the organizational innovation culture $(\mathrm{n} 1)$ ".

According to Kiuru (2015), cultural aspects in organizations are much more essential ones to overall innovativeness than any other aspects. He continues that manager's abilities to encourage employees are essential factor for organizational innovativeness. He states that this kind of encouragement will shape values in organization as well as organizational culture over time.

Kiuru's thoughts are quite similar to related literature and Rogers (1995: 35) arguments that it is crucial for innovativeness that the innovation is communicated through certain channels over time among the members of a social system. He continues that communication is a process where participants create and share information on the innovation in order to achieve mutual understanding (Rogers 1995: 6). According to Schein (2004:14) the word "culture" adds many other crucial elements to the concept of sharing. These are structural stability, depth, breadth and pattering or integration (Schein, 2004:14-15). The culture is something that lies very deep in groups and its individuals and make organization act or behave in a rather similar and coherent way. Therefore, changing organizational culture could be difficult without understanding of its aspects, which appears to be the problem in Finnish construction companies.

In homogenous organizations, the culture of behaving is similar because existing organizational culture guides to behave in a coherent way as Hofstede (2010) has shown us. These characteristics may lie deep in organizations and may guide to increase homogeneity especially when recruiting employees. Organizations can be blind for this development. One of the very describing comments from construction company is as follows,

"we should have new ideas for example steering of design because our employees are homogeneous by their educational backgrounds (n5)",

which quite clearly indicates that there may be a need for a totally new kind thinking in the construction industry organizations. Especially in Finnish construction business, it seems that employees come homogeneous educational backgrounds to work in homogeneous organizations and therefore they fit well in these organizations and their existing cultures. According to Green \& Cluley (2014) organization culture, dynamics and structures with diversity facilitates innovation. Ruiz-Jiménez et al. (2016) states that diversity in organizations and its management moderates product and process innovation positively. This lack of diversity in construction companies may not be encouraging when considering innovative organizations or creating innovative culture in organizations where managers must have essential role. It may even be sector level vicious cycle in affecting negatively in overall innovativeness of the construction companies. Organizational diversity is often seen as a highly important element when 
creating innovativeness or new combinations for new ideas as Schumpeter (1934) has shown us. Therefore, education of future leaders may need to be re-think and construction organizations need to change radically their HR-practices when recruiting.

It seems that organizations where is less diversity are not as innovative and suffering lack on innovative organizational culture. Parolin et al. (2013) paraphrase Tether (2002) that innovation cooperation needs active participation within the organization and especially with other organizations. They continue that joint collaboration with other organizations does not imply immediate benefits from the venture and contracting work in its content is not considered as collaboration (Parolin et al. 2013). Organizations in construction industry must accept that innovations and sustainability need resources with active involvement. This means that there may not be quick profits available in this kind of development although there are recent research indications that sustainability most likely increase revenues in construction. Innovations, innovation management and management of innovative organizational culture should be seen as a company level strategy, which will lead success and innovativeness over time. It appears that in construction industry there are difficulties to understand these aspects including innovative organizational culture which is decreasing sector level innovativeness in Finnish construction business.

\section{Methodology}

The main purpose of this paper is to find out connections in organizational culture, innovativeness and sustainability in Finnish construction industry. To build up a more complete understanding of the methods how organizations can construct an innovative culture in order to achieve more sustainable approaches in construction industry, we used a case study method to research this empirical phenomenon. Therefore, we are suggesting quite generalizable conclusions and we used an abductive approach to bring in new contributions to existing theory of organizational culture and innovativeness connected to sustainability in Finnish construction business and sector level transitions towards sustainability (Eisenhardt \& Graebner, 2007).

This study is a case study of a Finnish construction company and based on the empirical evidence collected by interviews and literature research. Organizational innovativeness and innovative organizational culture are phenomena in the organizational context of companies. According to Yin (1981), one of the features of a case study is that it examines a contemporary phenomenon in its real life environment. The case study research method is rather flexible and allows utilize methods such as interviews, use of existing documentation and observation. As a research strategy, the case study is a suitable option for examining research questions that are seeking answers to a phenomenon (Yin, 1981). This approach emphasis use of research approaches such as qualitative research through semi-structured thematic interviews with interpretative and summative content analysis in real-life context (Table 2).

\subsection{Case background}

Innovation management and sustainability in construction industry has been a subject of intensive research during recent years. Nevertheless, linking innovative organizational culture and sustainability in construction is far more less researched topics in construction sector. According to recent research of Kajander (2016) construction companies needs disruptive or radical sustainability innovations because of urgent global challenges. He continues that construction industry has a huge impact to global economy and therefore holds on major role how sustainable our future will be. He highlights that construction industry can receive financial benefits by adopting more sustainable approaches and sustainability innovations increases shareholder value significantly in construction (Kajander, 2016).

It is obvious that construction companies must open possibilities for constant innovation. In here, understanding the importance of generating innovative organizational culture to construction industry organizations is essential. Organizational climates must be supportive and couraging to take rather radical perspective to innovativeness which can have major impacts to sustainability and financial performance 
of the companies in construction sector. Therefore, examining innovativeness and its connections to sustainability is highly important to environment and industry itself.

\subsection{Data collection}

Examining innovation management in an organizational context is more like examining a phenomenon existing in the case setting of the organization. The semi-structured interview method highlights the interpretations of the interviewer and it takes into consideration interviewees' own opinions based on the experience of the issues discussed (Hirsjärvi \& Hurme 2000: 47-48). In this study the primary data collection method was 14 semi-structured thematic interviews with an intensive literature review.

According to Barret et al. (2007) there are three different levels where innovation occurs in the construction business: sector level, business level, and project level. Therefore, interviewees were chosen with a diversity of different positions and experience in organization, but in a way that they had a broad view of the different operations, business lines and functions in the case company (Table 3). The results of the data collection and interviews represent strong empirical evidence regarding the topic of this paper. Collecting and selecting data in this way supports well purposes of researching links between organizational culture, organizational innovativeness and sustainability.

\subsection{Data analysis}

According to Gubrium \& Holstein (2002: 83-85), finding out meanings in the transcribed interviews, or other data, is an essential part of every qualitative research. One way of analyzing the meanings from the qualitative data is based on content analysis and its method is called summarizing. Flick et al. (2004: 268) argue that summarizing content analysis is a procedure where the ways of reducing large amounts of collected data reveals the relevant content in a manageable and short way. Elo et al. (2008) supports Flick et al. arguments saying that the content analysis method can be used with qualitative data and it is very suitable for different analysis. Therefore, the primary analysis method used in this study is interpretative and summative content analysis.

Due to the nature of this study and ensuring validity of collected data the interviewees are categorized anonymous as n1, n2, n3...n12 when cited. This was relevant in order to get the best possible information from professional working on organization at the time of interviews. This method with semi-structured interviews was used in means to get interesting insights from interviewees, how they construct reality and think in different situations related to innovative organizational culture and sustainability in this particular case (Yin 2012).

Table 2. Summary of the research methodology and research approaches

\begin{tabular}{|l|l|}
\hline Research approach & Qualitative research, abductive \\
\hline Research method & A case study method \\
\hline Data collection approach & Interviews \\
\hline Data collection method & Semi-structured thematic interviews \\
\hline Analysis approach & Interpretative \\
\hline Analysis method & Content analysis, summative \\
\hline
\end{tabular}




\section{Key elements of managing innovative culture towards sustainability in construction}

As we have seen from this paper, managing innovative culture is not usually well done or adopted by managers which have impacts of using new sustainable solutions and approaches. Table 3 introduces main considerations as a results from interviews made in the case company.

Table 3: Table of the considerations of respondents as interview script

\begin{tabular}{|c|c|c|c|}
\hline $\begin{array}{c}\text { Interviewee title in the } \\
\text { organization }\end{array}$ & Cited & Keywords & Duration \\
\hline $\begin{array}{l}\text { Senior Vice President, } \\
\text { Housing Business } \\
\text { Development, Brand }\end{array}$ & $\mathrm{n} 1$ & $\begin{array}{l}\text { organization culture, pragmatic, major } \\
\text { problem, innovation culture, management by } \\
\text { results, hard to implement, new thing differs } \\
\text { from, existing processes }\end{array}$ & $56 \mathrm{~min}$ \\
\hline $\begin{array}{l}\text { Senior Vice President, } \\
\text { Business Development }\end{array}$ & $\mathrm{n} 2$ & $\begin{array}{l}\text { Innovation management, leading, manager's } \\
\text { capability, competence, lead innovations, } \\
\text { motivate, remarkable challenges, } \\
\text { implementation, matrix organization }\end{array}$ & $72 \mathrm{~min}$ \\
\hline $\begin{array}{l}\text { Head of Development, } \\
\text { Building Construction }\end{array}$ & n3 & $\begin{array}{l}\text { sufficient, advantage, learning methods, very } \\
\text { few methods, work circulation, cooperation, } \\
\text { know-how, benchmarking, mentoring, lots to } \\
\text { improve, learning, organized, goal oriented, } \\
\text { culturally strong, not support, knowledge } \\
\text { sharing, no common way, culture to } \\
\text { communicate, the deficiency, communication } \\
\text { channels, innovation management, } \\
\text { information, issue of management atmosphere, } \\
\text { created, improve innovativeness }\end{array}$ & $96 \min$ \\
\hline Development Manager, IT & $\mathrm{n} 4$ & Not cited in the article & $86 \mathrm{~min}$ \\
\hline $\begin{array}{l}\text { Human Resource Manager, } \\
\text { HR }\end{array}$ & n5 & $\begin{array}{l}\text { new ideas, steering of design, employees, } \\
\text { homogeneous, educational backgrounds }\end{array}$ & $86 \mathrm{~min}$ \\
\hline $\begin{array}{l}\text { Senior Vice President, } \\
\text { Development of Building } \\
\text { Construction and } \\
\text { Infrastructure }\end{array}$ & n6 & $\begin{array}{l}\text { line organizations, result-oriented, idea, } \\
\text { gaining results, won't be successful }\end{array}$ & $46 \mathrm{~min}$ \\
\hline $\begin{array}{l}\text { Development Manager, } \\
\text { Housing Business }\end{array}$ & $\mathrm{n} 7$ & $\begin{array}{l}\text { Organizations, strong culture, a result-oriented } \\
\text { way, built up, into the organization, very hard, } \\
\text { cooperate, how to proceed together }\end{array}$ & $66 \mathrm{~min}$ \\
\hline $\begin{array}{l}\text { Quality and Development } \\
\text { Manager, Infrastructure }\end{array}$ & $\mathrm{n} 8$ & Not cited in the article & $55 \mathrm{~min}$ \\
\hline $\begin{array}{l}\text { Product Manager, Housing } \\
\text { Business }\end{array}$ & n9 & Not cited in the article & $58 \mathrm{~min}$ \\
\hline $\begin{array}{l}\text { Project Manager/Site } \\
\text { Supervisor }\end{array}$ & n10 & much more, innovativeness, construction & $76 \mathrm{~min}$ \\
\hline $\begin{array}{l}\text { Administration Manager, } \\
\text { Building Construction }\end{array}$ & n11 & Not cited in the article & $99 \min$ \\
\hline Senior IT-Manager, IT & $\mathrm{n} 12$ & $\begin{array}{l}\text { organization structure, scattered, over } 30 \text { small } \\
\text { construction companies, own way, doing } \\
\text { things, environment very hard, develop } \\
\text { anything }\end{array}$ & $45 \mathrm{~min}$ \\
\hline
\end{tabular}

Nevertheless, managing culture is exactly what should be done in the case of construction industry and its transitions towards sustainability. In research, organizational culture has been conceptualized being a mediator of the affiliation between transformational leadership, organizational innovativeness and performance (Amabile et al. 1996; Deshpande et al. 1993; Jassawalla \& Sashittal, 2002; Prather \& 
Turrell, 2002, Xenikou \& Simosi, 2006). According to Yesil, \& Kaya (2012) it is essential to organization be able to create an organizational culture which can create innovation supportive environments. Miron et al. (2004) argues that organizational culture is viewed as a foundation of sustained competitive advantage.

As we have seen from Schein's (2004) studies leaders must lead culture and changes. This includes some rather radical methods such as challenging their own organization's working habits. According to Ramazani \& Jergeas, (2014) project managers are not familiar with the variety of needed aspects in efficient project management arguing that they do not use innovative learning environments and techniques in their work. They continue that project management studies concentrate on technical and operational skills instead of actual skills on how to lead people in projects. They state that in education there are lacks in learning leadership abilities, effective communication and especially in inspiring and motivating project groups (Ramazani \& Jergeas, 2014). According to Yusof et al. (2016), the construction industry can significantly contribute environmental sustainability. They continue that in research, environmental quality is often associated with human behaviours and therefore it is crucial to facilitate environmental sustainability in the construction sector organizations. In traditional industry, where educational background is more or less similar and career paths typically go from sites to company level positions, do not support an active leading style with facilitation methods or leading an innovative culture with sustainable approaches.

Culture seems to be defined broadly, but according to Schein (1990:111) definition of organizational culture is

"a pattern of basic assumptions that a group has invented, discovered or developed in learning to cope with its problems of external adaptation and internal integration, and that have worked well enough to be considered valid, and therefore, to be taught to new members as the correct way to perceive, think, and feel in relation to those problems".

According to Schein's definition, culture seems similar behaviour adapted by a group or an organization. James et al. (2007) described culture as the normative beliefs and shared behavioural expectations, i.e. system values and system norms, in an organization. Therefore, managing the people in organizations towards innovativeness is essential. As the following argument shows, there are difficulties of managing people in the case company:

"We can't take advantage sufficiently of different learning methods. I mean we use very few methods like work circulation, cooperation, getting to know how others do their work, benchmarking and mentoring. Here we have lots to improve and we should make learning more organized and goal oriented (n3)".

This argument indicates that there is no culture of using these vital methods for increasing innovativeness. When trying to change organizational culture towards innovativeness, the wide use of different practices is crucial, as Schein (2004) has pointed out. Kiviniemi (2015) states that ability to renew and be innovative is highly important to construction industry organizations. He argues that especially values and how values are led by managers have significant roles creating innovative organizational culture. Lack of diversity in organizational context, difficulties to lead culture and homogeneous organizations could be behind construction industry's non-innovative way of working just as anthropological research of culture and leaders has shown us.

Furthermore, homogeneity in organizations human resources, manager's rather similar backgrounds and pragmatic way of thinking with long career paths may be a significant barrier against innovativeness and sustainability in Finnish construction companies. Delgado-Verde et al. (2016) connects organizations intellectual capital to its capability to produce radical innovations. As we can see from the following statement of senior manager, there are difficulties to lead innovations in construction: 
"Innovation management starts with the way of leading. What is our manager's capability or
competence to lead innovations and motivate their employees (n2)"?

It appears that the problem observed in the case company is very similar to the research arguments presented earlier with indications that the typical organizational structure in Finnish construction industry increases these problems. Organizational structure that is not corresponding to innovativeness in highly result-oriented environments may even build up non-cooperative non-innovative culture with strong subcultures where only traditional approaches are supported. Next comment may indicate these problems a more profound way:

"Culturally strong business units do not support knowledge sharing (n3)",

which is one of the major problems against organizational innovativeness of the case company. As Teece (1996) has stated, organizational structure should correspond to the type of innovation. It seems that the typical organizational structure in Finnish construction industry, result oriented approaches and a difficulty to manage culture is not supportive for innovations.

Difficulties managing innovative culture can reflect to organizational learning, cooperation or communication that is essential to innovativeness and usage of sustainable solutions in the industry. According to Beugelsdijk et al. (2006) and Christensen \& Gordon (1999), organizational culture is specific to an organization, is relatively constant and can influence inter-organizational relations. Next comments from the case company indicates something similar but negative way:

"There is no common way or culture to communicate, as stated before and this is caused by the deficiency in communication channels (n1)" or "innovation management is an information channel matter, but it is of course also the issue of management so that an atmosphere is created to improve innovativeness (n3)".

As Tapilo \& Taskinen (2006) have shown us, innovative organizational culture needs innovation structures to be successful. It seems that in Finnish construction industry there is rather little understanding of organizational culture and its effect to innovativeness.

In the case company, there are indications of severe difficulties in internal and external cooperation. The next statement describes these matters well:

"In our organizations we have a strong culture of a result-oriented way of doing things and it is built up to into the organization. It is very hard to cooperate and settle how to proceed together. (n7)".

It appears that understanding of organizational culture or its effects to innovativeness in the case company is not sufficient. According to Apilo \& Taskinen (2006:35-36) innovative organizations is dazzling between organizations of chaotic creativeness and organizations with high bureaucracy. They argue that innovative organization culture has features like knowledge sharing, tolerance of mistakes, good collaboration abilities and variation in resources with different kinds of educational backgrounds including an ability to see mistakes as learning opportunities, just a few to mention (Apilo \& Taskinen 2006:36). These features are highly important for innovativeness in the organizations. It seems that organizations in Finnish construction industry have failed their attempts to create more innovative solutions because of the culture of these organizations.

Maybe one of the best ways to reflect the innovative culture in organization is through implementation processes. This is because in implementation there is a need for profound collaboration and communication through the whole organization especially if matrix kinds of structures are involved. The 
next arguments given by senior leaders and managers of the case company reveal highly interesting aspects of the case company's organizational culture.

"Culture of management by results is strong in business units, so it is very hard to implement any new thing which differs from normal or existing processes ( $n 1)$ ".

"There are remarkable challenges in implementation. Especially things developed in the matrix organization are very hard to implement in business units (n2)".

"Our line organizations are so result-oriented that if an idea does not help in gaining results it won't be successful at all (n6)".

"Our organization structure is scattered. The truth is that we have here over 30 small construction companies with their own way of doing things. In this kind of an environment it is very hard to develop anything at all (n12)".

It seems to be that there is no culture of doing things together and strong business lines are not collaborative in their actions. It appears that result oriented way of working together with a culture of pragmatic approaches is very hostile to anything which is new or something which will change to existing working habits. It seems that in the case company there is no culture of doing things together and the organizations' management has not succeeded to generate collaborative culture in the case company. This refers to similarity of the anthropological research of culture and leaders where managers are part of exiting culture and therefore they have difficulties to change organizational culture towards innovativeness. Therefore, to create an innovative organizational culture diversity is highly needed for Finnish construction companies.

It seems that organizational culture and the manager's abilities to support and lead innovative culture is the key element towards increased innovativeness in Finnish construction industry and in the case company as we have seen from table 1 and table 3 . This means that patterns that are making the organization rather homogeneous may need to be broken and new combinations should be built in the organization and its business lines just as Schumpeter (1934) has shown us. Existing managers has to renew their thinking and be open-minded towards cultural changes with abilities to challenge their own organizations working habits.

Managers should be more collaborative and communicative with use of variety of facilitation methods when leading their employees. Human resource practices need to be changed in a way where they create diversity and support forming an innovative organizational culture. Recruitment practices that seek new characteristics in employees are highly recommended in this process. According to Kiviniemi (2015), Kiuru (2015) and Cho et al. (2016) mangers abilities to shape organizations organizational culture is crucial for innovative construction. Therefore, key element increasing organizational innovativeness and sustainability in the case company is the ability to shape organizational culture towards innovativeness.

\section{Discussion}

It is paradoxical that the construction industry operates by its nature in a way like innovation management theories indicates and in future industry organizations will face significant sustainability challenges in rather complex environments. This gives plenty of opportunities and market demand to be innovative. Still the industry is considered as non-innovative and traditional. It appears that innovation management is something that is not seen as important in construction companies because of pragmatic and resultoriented way of thinking. It seems that the culture in these companies is against innovativeness and sustainability. It would be very delighting to see further research in how organization culture can be seen as a one of the key elements when increasing innovativeness in construction business and what kind of negative impacts there will be in innovativeness if organizations are too homogeneous? Especially 
interesting would be studies related to the anthropological thoughts about leaders and culture in context of construction industry.

As we have seen in this paper manager's abilities to manage soft issues like organizational culture and people should be better. It appears that managers' abilities to use a variety of leadership kind of leading methods are not at a sufficient level in Finnish construction business and operative way of working is dominating. It is logical that managers' which are skilled in managing soft issues such as people and culture are not validate in recruitment processes which seek only candidates corresponding to exiting result-oriented, pragmatic and operative organizational culture. Therefore, studies which examine the organizations culture and its effects to actual recruitment processes and characteristics of newcomers could be very interesting ones. Especially if organizational culture needs to be changed which kind of characteristics in mangers are the ideal ones to accomplish these changes and how these characteristics differ from typical or existing manager characteristics?

One of the key elements of organizational innovativeness, as well as diffusion of innovations is collaboration and communication. According to this study there are severe difficulties regarding both of these aspects in the case company. This paper indicates that strong business lines and units are very problematic when it comes to all kind of collaboration. It still does not explain why there is no culture of cooperation? For these reasons, studies of communication and collaboration in the Finnish construction industry with organizational culture besides structural aspect would be highly interesting.

Studies that examine educational aspects in construction sector and how future managers are educated on leadership style, human centric leadership, organizational culture and innovativeness could be very useful. Research of sustainability presented in this paper strongly indicates that there are straight connections with sustainability performance and organizational competitiveness. Therefore, research that will indicate sustainable development as an opportunity for construction industry organizations could be highly relevant. In addition, research that try to link sustainable development and managing innovative organizational culture in the construction industry organizations is warmly welcome.

\section{Conclusions}

The main purpose of this paper is to find out connections in organizational culture, innovativeness and sustainability. More precisely is it possible to thrive towards increased innovativeness and sustainability through organizational culture in Finnish construction industry. One of the most discussed actions in organization when trying to change the organizations culture is its values. As we have seen from Schein's (2004) research it seems that cultural aspects in organizations are far deeper. Hogan et al. (2014) have shown us that the layers in organizational culture support innovations. It appears that in traditional environments only shattering the existing structures in the organizations can bring the needed cultural changes and development towards innovativeness and sustainability. There may be subcultures in organizations which need to be examine well when trying to change overall organizational culture. There are indications that in the case company strong business lines including their business units should be more collaborative and open to changes in their culture towards new way of working. It seems that change can occur only creating diversity in these organizations as this paper indicates. In the case company, there are urgent need for recruiting managers and leaders with characteristics different from traditional ones.

It appears that the focus of increasing innovativeness in the case company is not on cultural aspects and therefore reasons to be non-innovative is hidden. This may be a result of manager's homogeneity in organization and organizational blindness to its own operations as anthropological view of culture and leaders have pointed out. As a result, it may imply that in very effective and result oriented environments managers and leaders can thrive with their strong operative abilities when there is no interest or even capabilities of managing culture to increase innovativeness. It seems that in construction there is no need 
to considering these aspects because similar thoughts are easily acceptable. These strong environments are built-up by organization themselves because of the exiting organizational culture is encouraging to do so. This aspect might even increase homogeneity in these organizations. Therefore, profound changes in the organizational culture of the case company and other construction companies in Finland is needed aiming for increased sector level innovativeness.

According to research presented in this paper, it is essential that organizations are able to renew their culture. In the case company, it appears that there is no sufficient culture of collaborating with internal or external organizations. As Tether (2002), Parolin et al. (2013) and Reypens et al. (2016) have shown us with several other researchers collaboration and communication are essential to innovativeness. What comes to the case company there seem to be severe difficulties to collaborate or even communicate properly. One of the main suggestions in this paper is that the case company builds up innovation infrastructure and generates an open, learning oriented and collaborative culture within organization including stakeholders.

It appears that experienced managers are not able to change their approaches and act like "learning leaders" in cultural change as Schein (2004) has pointed out. It also seems that these kinds of characteristics are not something that can be easily learned although exactly these characteristics are essential for organizations innovation productivity (Cho et al. 2016). For these reasons human resource practices should take into account the need for diversity in the traditional organizations, encourage employees in an active work circulation and cooperation. These actions could change organizational culture towards more innovative practices that most probably will increase the case company's competiveness and innovativeness.

This paper has shown us that organizational culture seems be a key aspect of innovativeness and sustainability in construction. Nevertheless, only profound changes in the case company's culture will increase its innovativeness. As Tapilo \& Taskinen (2006) have pointed out, if organization is aiming to be innovative it needs innovation strategies, structures and processes. All of these aspects are more or less unsuccessful without the innovative organizational culture that drives them towards innovativeness. We have seen from Schein's (1990), Hofstede (2010) and James et al. (2007) studies that organizational culture is considered as rather similar behaviour in groups or organization. Therefore, organizational culture can have negative effects on the organization generating unwanted features that seem decreasing innovativeness in construction.

Organizational culture must facilitate innovations as Green \& Cluley (2014), Arundel et al. (2015) and Schøtt \& Jensen (2016) have studied. One of the main finding of this paper is that the anthropological perspective about culture and leaders seems to be right considering the collected empirical evidence from case company and despites that in research the functionalist perspective is in favour (Table 1). This study has pointed out that managers in case company seems to unable to change the existing organizational culture because they are not apart from it. It appears that organizational culture and diversity hold on the answers of the increasing innovativeness and sustainability including cleaner production in the Finnish construction industry and the case company. 


\section{References}

Amabile, T. M., Conti, R., Coon, H., Lazenby, J., Herron, M. (1996). Assessing the work environment for creativity. Academy of Management Journal, 39(5): 1154-1184.

Apilo, T., Taskinen., T (2006). Innovaatioiden johtaminen. VTT:n tiedotteita 2330, Helsinki. ISBN 95138-6775-7 (URL: http://www.vtt.fi/publications/index.jsp), ISSN 1455-0865 (URL:

http://www.vtt.fi/publications/index.jsp).

Arundel, A., Casali, L., Hollanders, H. (2015). How European public sector agencies innovate: The use of bottom-up, policy-dependent and knowledge-scanning innovation methods. Research Policy, 44(7): $1271-1282$.

Alwan. Z., Jones, P., Holgate, P. (2016).Strategic sustainable development in the UK construction industry, through the framework for strategic sustainable development, using Building Information Modelling. Original Research Article Journal of Cleaner Production, In Press, Corrected Proof, Available online 12 January 2016.

Bartsch, V., Ebers, M. and Maurer, I. (2013) 'Learning in project-based organizations: the role of project teams' social capital for overcoming barriers to learning', International Journal of Project Management, 31(2):239-251.

Barrett, P., Abbott, C., Ruddock, L. \& Sexton, M. (2007). Hidden innovation in construction and property sectors, RICS Research Paper Series, 7(20), RICS, London. ISBN 978-1-84219-359-4, ISSN 1464$648 X$.

Beugelsdijk, S., Koen, C. I., \& Noorderhaven, N. G. (2006). Organizational culture and relationship skills. Organization Studies, 27(6): 833-854.

Blayse, A. M., Manley, K. (2004). Key influences on construction innovation, Innovation: Information, Process, Management, 4(3):143-154.

Bygballe, L.E., M. Ingnemasson. (2014). The logic of innovation in construction. Industrial Marketing Management. In Press, available online 18 January 2014.

http://dx.doi.org/10.1016/j.indmarman.2013.12.019

Chapman, R., Hyland. P. (2004). Complexity and learning behaviours in product innovation. Technovation, 24(7):553-561.

Chesbrough, H.W. (2003). Open Innovation: The new imperative for creating and profiting from technology. Boston: Harvard Business School Press, USA. ISBN: 1-4221-0283-1.

Cho, C., Halford, J.T., Hsu, S., Ng, L. (2016). Do managers matter for corporate innovation? Journal of Corporate Finance, 36, February: 206-229.

Christensen, E. W., \& Gordon, G. G. (1999). An exploration of industry, culture and revenue growth. Organization Studies, 20(3): 397-422.

Delgado-Verde, M., Martín-de Castro, G., Amores-Salvadó, J. (2016). Intellectual capital and radical innovation: Exploring the quadratic effects in technology-based manufacturing firms. Technovation, in press, corrected proof, available online 23 February 2016.

Damanpour, F. (1991). Organizational innovation. meta-analysis of effects of determinants and moderators. Academy of Management Journal, 34(4):555-590. 
Damanpour, F., Schneider, M. (2006). Phases of the adoption of innovation in organizations: Effects of environment, organization and top managers. British Journal of Management, 17(3): 215-236.

Denison, D. R., \& Mishra, A. K. (1995). Toward a theory of organizational culture and effectiveness. Organization Science, 6(2):204-223.

Deshpande, R., Farley, J. U., \& Webster, F. E. (1993). Corporate culture, customer orientation, and innovativeness in Japanese firms: A quadrad analysis. Journal of Marketing, 57(1): 23-27.

Elo, S., Kyngäs, H. (2008). The qualitative content analysis process. Journal of Advanced Nursing 62:1, $107-115$.

Eisenhardt, K. M., Graebner, M. E. (2007). Theory building from cases: opportunities and challenges. Academy of Management Journal, 50 (1), 25-32.

Eriksson, P.E. (2013). Exploration and exploitation in project-based organizations: development and diffusion of knowledge at different organizational levels in construction companies. International Journal of Project Management, 31(3):333-341.

Flinck, U., Kardoff, E.V., Steinke, I. (2004). A companion to qualitative research. London. Sage Publications Ltd. ISBN 076197374

Gann, D.M. (2001). Putting academic ideas into practice: technological progress and the absorptive capacity of construction organisations, Construction and Economics, 19(3):321-330.

Gann, D.M., Salter, A. (2000). Innovation in project-based, service-enhanced firms: The construction of complex products and systems, Research Policy, 29(7-8):955-972.

Gosling, J., Mintzberg, H. (2004). The education of practising managers, MIT Sloan Management Review, 45(4):19-22.

Green, W., Cluley, R. (2014). The field of radical innovation: Making sense of organizational cultures and radical innovation. Industrial Marketing Management, 43(8): 1343-1350.

Gubrium, J.F., Holstein, J.A. (2002). Handbook of interview research: Context \& Method. London. Sage Publications. ISBN 0761919511.

Hirsjärvi, S., Hurme, H.(2000). Tutkimushaastattelu: Teemahaastattelun teoria ja käytäntö. Helsinki. Yliopistopaino. ISBN 9515704588.

Hofstede, G., Minkov, M. (2010). Cultures and Organizations: Software of the Mind. McGraw-Hill Education; third edition, ISBN-13: 978-0071664189.

Hogan, S.J., Coote, L.V. (2014). Organizational culture, innovation, and performance: A test of Shein's model. Journal of Business Research, 67(8):1609-1621.

James, L. R., Choi, C. C., Ko, C.-H. E., McNeil, P. K., Minton, M. K., Wright, M. A. (2007). Organizational and psychological climate: A review of theory and research. European Journal of Work and Organizational Psychology, 17(1): 5-32.

Jassawalla, A. R., \& Sashittal, H. C. (2002). Cultures that support product innovation processes. Academy of Management Executive, 16(3): 42-54.

Kajander, Juho-Kusti. (2016). Evaluation of sustainability innovations in the construction sector. Aalto University publication series. Doctoral Disserations, 158/2016, ISBN:978-952-60-6957-9 
Kane, K.R., Goldghen, L.A. (2001). Beyond the total organization: A graduate -level simulation, Journal of Management Education, 35(6):836-858.

Kessler, E. H., Chakarbati, A. K. (1996). Innovation speed. A conseptual model of context, antecend and outcomes. Academy of management Review, 21(4):1143-1191.

Kotler, P., Ainamo, A. \& Ranta, H. (1990). Markkinoinnin käsikirja: analyysi, suunnittelu, toteutus ja seuranta. 6. uudistettu painos. Rastor-julkaisut, Helsinki: ISBN: 951941553X.

Kotter, J. (1998). Cultures and coalitions. Rethinking the future: Rethinking business, principles, competition, control \& complexity, leadership, markets and the world In R. Gibson (Ed.), London: Nicholas Brealey.

Lee, C-K., Tan, B. and Chiu, J-Z. (2008). Entrepreneurship, innovation and SME's and learning and human resources development, International Journal of Innovation and Learning, 5(4):413-428.

Ling, F. (2003). Managing the implementation of construction innovations, Construction Management and Economics, 21(6):635-649.

Liu, Y. (2013). Sustainable competitive advantage in turbulent business environments. International Journal of Production Research, 51(10):2821-2841.

Liu, Y., Liang, L., (2015). Evaluating and developing resource-based operations strategy for competitive advantage: an exploratory study of Finnish high-tech manufacturing industries. International Journal of Production Research, 53(4):1019-1037.

Martins, E. C., Terblanche, F. (2003). Building organisational culture that stimulates creativity and innovation. European Journal of Innovation Management, 6(1):64-74.

Matinaro, V., Liu, Y. (2015). Virtual design and construction: innovation process and diffusion in Finnish construction business, International Journal of Innovation and Learning, 18(2):133-150.

Matja., Maleti., Bo., Gomi., Ek. (2016). The impact of sustainability exploration and sustainability exploitation practices on the organisational performance: a cross-country comparison. Original Research Article. Journal of Cleaner Production, In Press, Corrected Proof, Available online 12 March 2016.

McLean, L. D. (2005). Organizational culture's influence on creativity and innovation: a review of the literature and implications for human resource development. Advances in Developing Human Resources, 7(2):226-246.

Meek, V. L. (1988). Organizational culture: Origins and weaknesses. Organizational Studies, 9(4):453473.

Meindl, J. R., Ehrlich, S. B., \& Dukerich, J. M. (1985). The romance of leadership. Administrative Science Quarterly, 30(1):78-102.

Miron, E., Erez, M., Naheh, E. (2004). Do personal characteristics and cultural values that promote innovation, quality, and efficiency compete or complement each other? Journal of Organizational Behavior, 25(2):175-199.

Muff, K. (2012). Are business schools doing their job? Journal of management Development, 31(7):648662. 
Nagano, M.S., Stefanovitc, J.P., Vick, T.E. (2014). Innovation management processes, their internal organizational elements and contextual factors: An investigation in Brazil, Journal of Engineering and Technology Management. 33 (July-September 2014):63-92.

Nonaka, I., Teece, D, (eds). (2001). Managing industrial knowledge: creation, transfer andutilization. Sage publications, London 2001, ISBN 0-7619-5498-8. Hardback. Referred from Knowledge and Process Management, 10(4):277-281, October/December 2003.

Ogbonna, E., Harris, L. C. (2000). Leadership style, organizational culture and performance: Empirical evidence from UK companies. International Journal of Human Resource Management, 11(4): 766788.

Parolin, S.R.H., Vasconcellos, E., Volpato, M., Laurindo, A.M. (2013). Barriers and Facilitators of Collaborative Management in Technological Innovation Projects. Journal of Technology Management \& Innovation. 8 (special issue ALTEC 2011)

Prather, C. W., \& Turrell, M. C. (2002). Involve everyone in the innovation process. Research Technology Management, 45(5): 13-16.

Pesonen, P. (2006). Innovaatiojohtaminen ja sen vaikutuksia metsäteollisuudessa. Espoo, VTT Publications 622. 110 p. ISBN 951.38.6878.8 (URL: http://www.vtt.fi/publications/index.jsp), ISSN 1455.0849 (URL: http://www.vtt.fi/publications/index.jsp)

Porter, M.E. (1985). Competitive advantage Boston, MA, Harvard University Press. ISBN: 9780684841465

Powell, J. A. (2007). Creative universities and their creative city-regions, Industry and Higher Education, 21(5):323-335.

Ramazani, J., Jergeas, G. (2014) Project managers and the journey from good to great: The benefits of investment in project management training and education. International Journal of Project Management. In press, corrected proof, available online 9 May 2014.

Reypens, C., Lievens, A., Blazevic, V. (2016). Leveraging value in multi-stakeholder innovation networks: A process framework for value co-creation and capture. Industrial Marketing Management. In Press, corrected proof, available online 24 March 2016.

Rosca, E., Arnold, M., Bendul, J.C. (2016). Business models for sustainable innovation - an empirical analysis of frugal products and services. Original Research Article. Journal of Cleaner Production, In Press, Corrected Proof, Available online 19 February 2016.

Rogers, E.M. (1995). Diffusion of innovations. 4th ed. New York. The Free Press, ISBN 0-02-874074-2 (cloth)-ISBN 0-02-926671-8 (paper).

Ruiz-Jiménez, J.M., Fuentes-Fuentes, M.d.M. (2015). Management capabilities, innovation, and gender diversity in the top management team: An empirical analysis in technology-based SMEs. BRQ Business Research Quarterly (2015), in press.

Ruparathna. R., Hewage. K. (2015). Sustainable procurement in the Canadian construction industry: current practices, drivers and opportunities. Original Research Article. Journal of Cleaner Production, 109, 16th December 2015: 305-314. 
Sarros, J.C., Cooper, B.K., Santora, J.C. (2008). Building a Climate for Innovation Through Transformational Leadership and Organizational Culture. Journal of Leadership \& Organizational Studies 15(2):145-158.

Schein, E. H. (1990) Organizational Culture. American Psychologist. 45 (2), 109-119.

Schein. E.H. (2004) Organizational culture and Leadership, 3rd. ed, San Francisco. US, ISBN:0-78796845-5

Schumpeter, J. A. (1934). The theory of economic development. Cambridge, Mass.: Harvard University Press.

Schneider, B., Goldstein, H. W., Smith, D. B. (1995). The ASA framework: An update. Personnel Psychology, 48(4):747-773.

Schøtt, T., Jensen.K. (2016). Firms' innovation benefiting from networking and institutional support: A global analysis of national and firm effects. Research Policy, 45(6): 1233-1246.

Smircich, L. (1983). Concepts of culture and organizational analysis. Administrative Science Quarterly, 28(3): 339-358.

Slaughter, S.E. (1998). Models of construction innovation, Journal of Construction Engineering and Management, 124 (3): 226-231.

Tabassi, A.A. Roufechaei, K.M., Ramli, M., Bakar, A.H.A., Ismail, R., Pakir, A.H.K. (2016). Leadership competences of sustainable construction project managers. Original Research Article. Journal of Cleaner Production, In Press, Corrected Proof, Available online 2 March 2016.

Tan, Y., Ochoa, J.J., Langston, C., Shen, L. (2015). An empirical study on the relationship between sustainability performance and business competitiveness of international construction contractors. Original Research Article. Journal of Cleaner Production, 93, 15th April 2015: 273-278.

Tatum, C.B. (1987). Process of innovation in construction firm, Journal of Construction Engineering and Management, 113(4):648-663.

Teece, D.J. (1996). Firm organization, industrial structure and technological innovation, Journal of Economic Behavior \& Organization, 31(29):193-224.

Tidd, J. (2001). Innovation management in context. environment, organization and performance, International Journal of Management Reviews, 3(3):169-183.

Trott, P. (2008). Innovation management and new product development. 4th ed. Harlow: FT Prentice Hall, Pearson Education, ISBN: 9780273713159

Tushman, M.L., Andersson. P. (1997). Managing startegic innovation and change. A collection of readings. ISBN 0-19-510011-5. New York, Oxford University Press.

Tushmann, M.L. and O'Reilly III, C.A (1997). Winning through Innovation:A Practical Guide to Leading Organizational Change and Renewal, Boston, MA: Harvard Business School Press.

Valencia, J.C.N., Valle, R.S., and Jiménez, D.J. (2010). Organizational culture as determinant of product innovation. European Journal of Innovation Management, 13(4):466-480. 
Vesa, Janne. (2014). Innovaatiotoiminnan johtaminen rakennustuoteteollisuudessa. Väitöskirja/Doctoral disseration. Tampereen teknillinen yliopisto/ Tampere University of Technology. Julkaisu/Publication 1251. Juvenes Print - Suomen Yliopistopaino Oy, TTY: ISSN: 1459-2045

Widén, K., Hansson, B., 2007. Diffusion characteristics of private sector financed innovation in Sweden, Construction Management and Economics. 25(5):467-475.

Winch, G.M. (1998). Zephyrs of creative destruction: understanding the management of innovation in construction, Building Research \& Information, 26(4):268-279.

Xenikou, A., \& Simosi, M. (2006). Organizational culture and transformational leadership as predictors of business unit performance. Journal of Managerial Psychology, 21(6):566-579.

Yesil, S., Kaya, A. (2012). The role of organizational culture on innovation capability: An empirical study, International Journal of Information Technology and Business Management, 6(1):11-25.

Yin, Y.K. (1981) ‘The case study crisis: some answers’, Administrative Science Quarterly, 26(1):58-65.

Yin, R.K. (2012). The applications of case study research. 3rd ed. London. Sage Publication Ltd. ISBN 978-1-4129-8916-9.

Yusof, N., Abidin, N.Z., Zailani, S.H.M., Govidan, K., Iranmanesh, M. (2016). Linking the environmental practice of construction firms and the environmental behaviour of practitioners in construction projects. Original Research Article. Journal of Cleaner Production, 121, 10th May 2016: 64-71. 


\section{Interviews}

Interviewed in January 2015, cited by names in the article

Kiuru, Pekka, Senior Vice President, Business Development, NCC Construction Company

Kiviniem, Tero, Vice President, YIT Ltd, Chairman of The Board, Confederation of Finnish Construction Industries RT 2015-, Member of the Board, Confederation of Finnish Industries 2015 -

Interviews were made in May-June 2014, cited by n1, n2, n3...in the article

Senior Vice President, Housing Business Development, Brand

n1

Senior Vice President, Business Development $\quad$ n2

Head of Development, Building Construction $\quad$ n3

Development Manager, IT $\quad \mathrm{n} 4$

Human Resource Manager, HR n5

Senior Vice President, Development of Building Construction and Infrastructure n6

$\begin{array}{ll}\text { Development Manager, Housing Business } & \mathrm{n} 7\end{array}$

$\begin{array}{lll}\text { Quality and Development Manager, Infrastructure } & \mathrm{n} 8\end{array}$

$\begin{array}{ll}\text { Product Manager, Housing Business } & \text { n9 }\end{array}$

$\begin{array}{ll}\text { Project Manager/Site Supervisor } & \mathrm{n} 10\end{array}$

$\begin{array}{ll}\text { Administration Manager, Building Construction } & \mathrm{n} 11\end{array}$

$\begin{array}{ll}\text { Senior IT-Manager, IT } & \mathrm{n} 12\end{array}$ 